\title{
New Communities on Eucalypts Grown Outside Australia
}

\author{
Sarah Mansfield * \\ Faculty of Agriculture and Environment, University of Sydney, Camperdown, NSW, Australia
}

\section{OPEN ACCESS}

Edited by:

Barbara De Lucia,

University of Bari Aldo Moro, Italy

Reviewed by:

Robert Scott Pfannenstiel,

Agricultural Research Service

(USDA), USA

Francesco Porcelli,

University of Bari Aldo Moro, Italy

*Correspondence:

Sarah Mansfield

sarah.mansfield@agresearch.co.nz

${ }^{\dagger}$ Present address:

Sarah Mansfield,

AgResearch Lincoln, Christchurch,

New Zealand;

Bio-Protection Research Centre,

Lincoln University, Lincoln,

New Zealand

Specialty section:

This article was submitted to Crop Science and Horticulture, a section of the journal

Frontiers in Plant Science

Received: 27 September 2016 Accepted: 16 November 2016

Published: 29 November 2016

Citation:

Mansfield S (2016) New Communities on Eucalypts Grown Outside

Australia. Front. Plant Sci. 7:1812.

doi: 10.3389/fpls.2016.01812
The expansion of eucalypt forestry worldwide has been accompanied by accidental and deliberate introductions of Australian insects associated with eucalypts. Local insect species have also colonized introduced eucalypts in many regions. This situation provides a unique opportunity to observe the development of new insect communities across trophic levels. Here the history of Australian invaders and native colonizers on eucalypts outside Australia is reviewed from the perspective of herbivore guilds: leaf chewers, sap suckers, wood borers, gall formers, termites. Historical patterns of invasion are identified across these guilds. Very few species of Australian leaf chewers, wood borers or termites have become widespread but these guilds are proportionately high in native colonizers. In contrast, sap suckers have multiple invasive species globally with relatively fewer native colonizers. The gall former guild also has several invasive species but so far includes no native colonizers, perhaps due to their tendency to have highly specific host plant associations. Natural enemies of Australian invaders are also members of new eucalypt insect communities, partly through planned biological control programs, but the rate of accidental introductions at higher trophic levels is increasing steadily. At the same time, local natural enemies enter eucalypt communities either to form new associations with Australian invaders or to follow native colonizers into this new habitat. Australian sap suckers have attracted far more new associations than other guilds so far. Native leaf chewers have often been followed by their local natural enemies into eucalypt communities, particularly in Brazil. Generally there are fewer records relating to local natural enemies and their role in new eucalypt communities. The complexity of new eucalypt communities outside Australia is expected to increase in future.

Keywords: biological control, Eucalyptus, herbivore guilds, invasive species, parasitoids, predators

\section{INTRODUCTION}

The worldwide expansion of eucalypt forestry (genera Angophora, Corymbia and Eucalyptus, Hui et al., 2014) has been accompanied by accidental introductions of Australian insect herbivores associated with eucalypts. Outside of their endemic geographic range (Australia for the majority of species, Wardell-Johnson et al., 1997), eucalypts represent distinct ecological communities that are vulnerable to more exotic arrivals. This dynamic situation provides a unique opportunity to observe the establishment of new insect communities across trophic levels in eucalypt plantations on a global scale. Recent work has used eucalypt communities to explore the 
characteristics of invasive species (Nahrung and Swain, 2015) and to evaluate the risk to Australian eucalypt plantations from invasion by exotic insect pests (Paine et al., 2011).

Beyond Australia, new invertebrate communities found in eucalypt forests elsewhere are formed not only through the invasion of Australian eucalypt specialist species but also through the colonization by local insect species (Ohmart and Edwards, 1991; Nair, 2007; Paine et al., 2011). The number of native species colonizing an exotic plant species increases with time after introduction (Brandle et al., 2008) so the potential for interspecific competition between Australian invaders and native colonizers on eucalypts should also increase with time. Competition would, in theory, be more intense between species from within the same herbivore guild than between those from different guilds (Denno et al., 1995). However, tests of this hypothesis have led to mixed results (Kaplan and Denno, 2007). The guild composition of Australian invaders has been described in exotic eucalypt stands in some regions (Withers, 2001; Paine et al., 2010) but the guild composition of native colonizers has received less attention.

The arrival of Australian invertebrate invaders often has been followed by the deliberate introduction of their co-evolved natural enemies to provide biological control (Garnas et al., 2012). Generalist predators and parasitoids that are native to the region may also form new associations with the Australian invaders (Santana and Burckhardt, 2007; Protasov et al., 2008). Similarly, native colonizers of eucalypts may be followed by their native natural enemies into the new community (de Oliveira et al., 2000; De Menezes et al., 2013). These processes ensure a gradual accumulation of species at higher trophic levels. The question is: have all of the herbivore guilds gained natural enemies to a similar degree?

In this contribution the history of eucalypt insect communities that have developed outside Australia is reviewed from the perspective of herbivore guilds, including both the Australian invaders and native colonizers, to compare the relative success of these two groups across different guilds. The accumulation of natural enemies (including deliberate introductions for biological control, accidental arrivals, and new associations) is also compared between the herbivore guilds in these new communities to determine if some guilds have acquired more natural enemies than others.

\section{RECORDS OF EUCALYPT INSECTS}

The published literature (up to June 2015) was searched using the Web of Science (all years and databases included: Web of Science, Current Contents, BIOSIS Previews, CAB Abstracts, Agricola). Also searched were the CABI Forestry and Invasive species compendia for all records of insects associated with eucalypts. From these records, a database of insect herbivores associated with eucalypts outside of Australia was prepared (Supplementary Material). This database included records of the country/countries showing an insect's association with eucalypts, the insect's country or region of origin, and in the case of Australian invaders, the year of the first record in each country was noted. The year of publication was used if the actual year of record could not be determined from the text. No attempt was made to differentiate between invasions that originated from Australia versus secondary dispersal by Australian invaders from their new areas of establishment into adjacent countries. For natural enemies associated with eucalypt herbivores, the prey or host species was also recorded. Generalist insect herbivores that are not confined to eucalypts in their native Australian range but instead feed on a broad range of plants that happens to include eucalypts were not included in further analysis.

\section{GUILD DEFINITIONS}

Eucalypt herbivores, irrespective of geographic origin, were grouped into the following feeding guilds: leaf chewers, sap suckers, gall formers, wood borers, termites, and others. Leaf chewers were chewing herbivores, mostly Australian and native Coleoptera and Lepidoptera, and native leaf cutting ants that have colonized introduced eucalypts in Central and South America (Speight and Wylie, 2001). Also included in this guild were two Australian eucalypt leaf miners (Phylacteophaga froggatti and Acrocercops laciniella) that have invaded New Zealand (Withers, 2001). Sap suckers (Hemiptera) included Australian psyllids as well as native species that colonized introduced eucalypts. Wood borers (mostly Coleoptera) were restricted to those that infest living trees; not included were wood boring species that feed only on dead logs or harvested timber. Various species of termites may feed on living trees (Pearson et al., 2010), tree roots (Zhenghong, 2003; Nair, 2007) or dead wood (Bain and Jenkin, 1983). Classification of termites in this study was problematic because it was not always possible to determine the appropriate guild for each termite species based on the available literature. Thus termites were treated as a separate group. Root feeders (other than termites) were not included as a separate guild because no Australian root feeders specific to eucalypts have been recorded as invaders. Native colonizers categorized as 'other' included generalist root feeders [often scarab larvae that attack seedlings (Zondag, 1979; Zhenghong, 2003)] and herbivores that could not be assigned accurately to a specific guild from the information available. Two Australian species were also categorized as 'other': a nectar feeding fly (Tribe et al., 1989) and a seed feeding thrips (Mound and Walker, 2012). These 'other' herbivores were excluded from further analysis.

\section{AUSTRALIAN INVADERS}

Today there are more than 40 Australian insect species associated with eucalypts that occur in at least one country beyond Australia (Withers, 2001; Paine et al., 2010) with 11 species now found in multiple countries. A further 29 species have reached just one country so far (Figure 1) (CABI, 2015a,b). Of the 11 most invasive eucalypt herbivores, the earliest began to disperse in the late 1800s. These included a leaf feeder Gonipterus platensis 


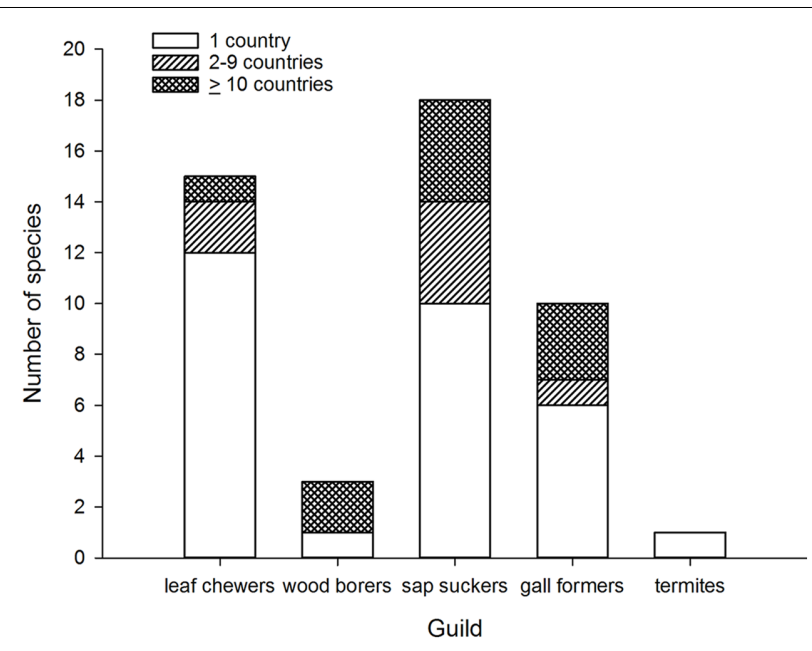

FIGURE 1 | Number of invasive species by number of invaded countries grouped according to guild of Australian eucalypt insects.

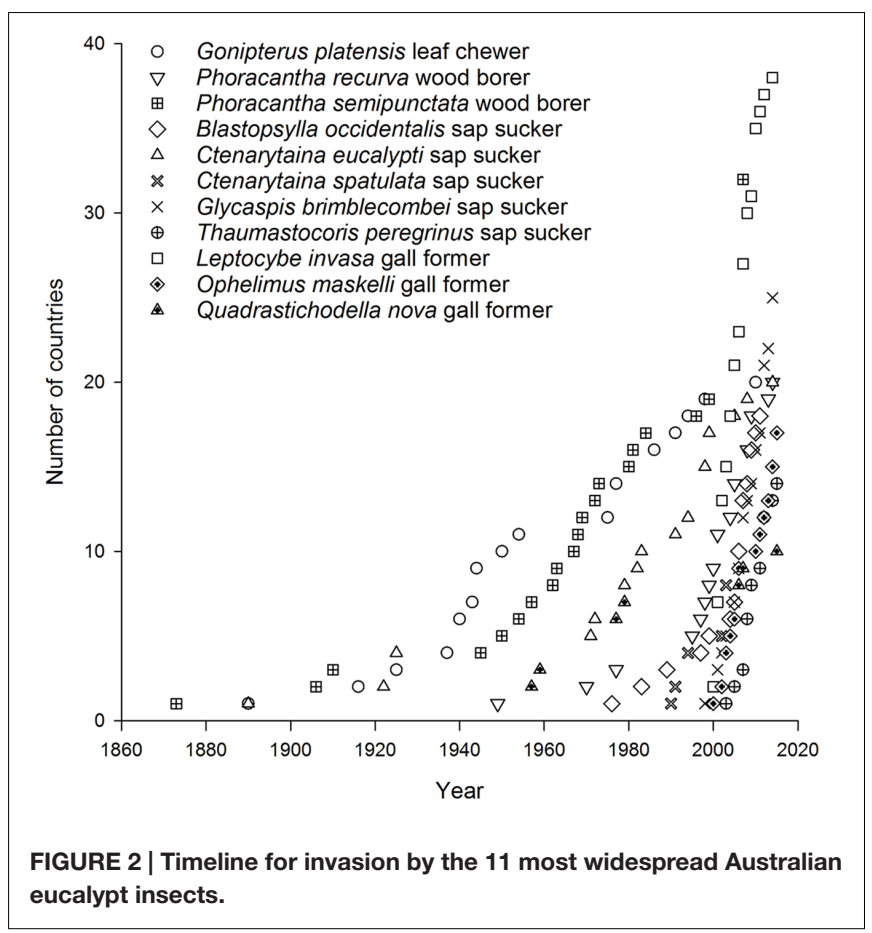

(previously known as G. scutellatus but now recognized as a cryptic species complex, Mapondera et al., 2012), a wood borer Phoracantha semipunctata, and a sap sucker Ctenarytaina eucalypti (Withers, 2001) (Figure 2). These species were followed in the mid-1900s by a second wood borer Phoracantha recurva (Drinkwater, 1975) and the first gall former Quadrastichodella nova (Timberlake, 1957). Thereafter a cluster of four sap suckers and two gall formers dispersed rapidly worldwide, beginning with Blastopsylla occidentalis and ending with Thaumastocoris peregrinus, which is the most recent Australian invader (Withers, 2001; Mendel et al., 2004, 2007; Noack and Coviella, 2006; Paine et al., 2010). Paine et al. (2011) identified two historical phases of movement for Australian eucalypt insects: early establishment was 1873-1955 and late establishment was after 1955. Certainly more recent invasions have spread faster than earlier events (this is evidenced in the timelines for P. semipunctata versus Leptocybe invasa, Figure 2). This trend is apparent even within the same guild. For example, it took more than 90 years for the first sap sucker, C. eucalypti, to disperse to ten countries whereas the most recent sap sucker invasion by $T$. peregrinus took only 8 years (Figure 2). Faster transportation rates, intensification of trade and the global expansion of eucalypt plantations have all contributed to the increasing speed of invasion events (Wingfield et al., 2008; Evans, 2009). These changes have increased the probability of invaders surviving the journey and finding suitable habitat upon arrival.

When broken down by guild, two patterns of colonization by Australian eucalypt insects become apparent. The first pattern shows a small number of dominant species within the guilds that are widespread globally; other guild members are only found in a restricted range outside of Australia. For example, two congeneric wood borers, the cerambycids $P$. semipunctata and $P$. recurva, have spread widely outside Australia (Paine and Millar, 2002) whereas the total number of invasive eucalypt wood borer species is low compared with other guilds (Figure 1). The implementation of biosecurity regulations has presumably restricted movement of wood borers, including termites, out of Australia (Commonwealth of Australia, 2015; Sopow et al., 2015) despite continued use of wooden packaging materials for shipping in many parts of the world (Rassati et al., 2015). The Australian termite, Porotermes adamsoni, attacks live eucalypts but is subject to eradication where it has established colonies in New Zealand (Pearson et al., 2010). Several generalist Australian termite species are now found in New Zealand (Bain and Jenkin, 1983; Withers, 2001; Philip et al., 2008) but were not included in this analysis. Among leaf chewers, only the G. platensis species complex is widespread with most other members of this guild being found in just one country outside Australia (often New Zealand). The lack of widespread invasion by most leaf chewers is not a reflection of narrow host ranges among guild members. For example, the eucalypt chrysomelid, Paropsis charybdis, colonized New Zealand in the early 1900s and has been recorded from $>60$ eucalypt species (CABI, 2015a) yet has not spread to any other eucalypt growing countries so far. More recent arrivals to New Zealand from the leaf chewer guild include Uraba lugens and Phylacteophaga froggatti, which both attack a wide range of eucalypts (Potter and Stephens, 2005; CABI, 2015a). Two leaf chewing species with potential for further spread are the eucalypt chrysomelids Trachymela sloanei, which has spread to New Zealand, South Africa and the USA (Withers, 2001; Paine et al., 2010), and Paropsisterna selmani, the first paropsine to reach Europe (Reid and De Little, 2013).

The second, more dispersive pattern, in contrast, has multiple invasive species within the same guild. This is demonstrated by the five species of sap suckers (including four psyllids) that have colonized 8-20 countries outside of Australia, with most of this expansion having taken place over the past 30 years (Santana and Burckhardt, 2007; Sopow et al., 2012). The sap sucker 


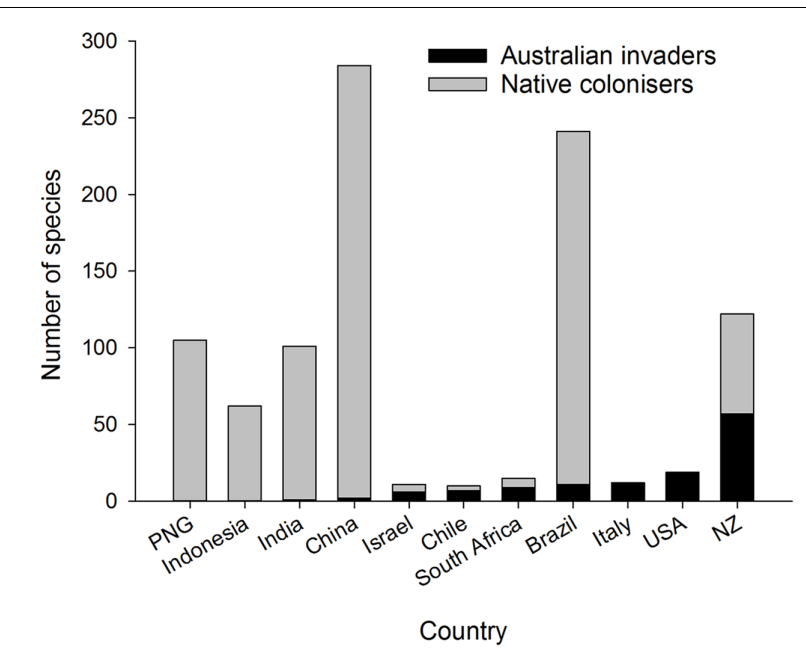

FIGURE 3 | Number of Australian invaders and native colonizers associated with eucalypts in different tropical and temperate countries. The number of Australian invaders increases from left to right.

B. occidentalis was the second Australian species associated with eucalypts to invade China (Yen et al., 2013). Those sap suckers with more restricted distributions are often found in New Zealand (Bejakovich, 2002; Martoni et al., 2016) although a new invasive species, Platyobria biemani, was recently found in Greece (Burckhardt et al., 2014). Gall formers also demonstrate this more dispersive pattern. The first member of this guild to become invasive was $Q$. nova, which now occurs in at least seven countries (Kim and La Salle, 2008; Paine et al., 2010). From 1999 a further nine species of gall formers have been found outside Australia for the first time (Berry and Withers, 2002; Protasov et al., 2007; Kim and La Salle, 2008) however, later work has suggested two of these species may be parasitoids, not gall formers (Klein et al., 2015). One species, L. invasa, has spread to 39 countries since 2000, the fastest invasion by any Australian insect associated with eucalypts (Garnas et al., 2012; Nugnes et al., 2015). This gall former was the first Australian eucalypt insect to enter China (Zhu et al., 2012) and India (Ramanagouda et al., 2010). Another species, Ophelimus maskelli, is recorded from 13 countries so far (Doganlar and Mendel, 2007; Branco et al., 2009; Burks et al., 2015b).

\section{NATIVE COLONIZERS}

A well-recognized pattern in eucalypt communities outside Australia is the dominance of local species colonizing eucalypts in tropical zones, whereas in temperate zones introduced species of Australian origin dominate the herbivore community (Ohmart and Edwards, 1991) (Figure 3). For example, many species of native termites are associated with introduced eucalypts in South America, southern China and India (Constantino, 2002; Zhenghong, 2003; Nair, 2007). There are some insect genera and species common to Southeast Asia, Papua New Guinea and tropical Australia (Common, 1980; Wang, 1995) but

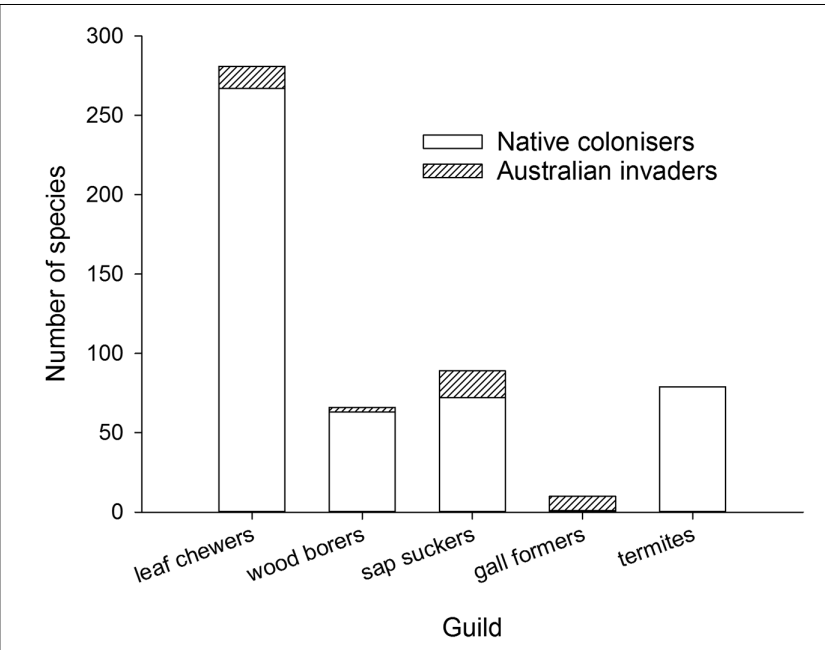

FIGURE 4 | Cumulative worldwide numbers of Australian invaders and native colonizers associated with eucalypts and grouped by guild.

very few endemic Australian insects have colonized eucalypts across Asia (Zhenghong, 2003) including China (Zhu et al., 2012; Yen et al., 2013) and India (Nair, 2007; Ramanagouda et al., 2010). The presence of either native eucalypts such as E. deglupta in Indonesia, East Timor, the Philippines and Papua New Guinea (Pryor et al., 1995) or other native Myrtaceae in South America, Africa and New Zealand may have pre-adapted local herbivores in those regions to colonize exotic eucalypts when the opportunity arose (Wingfield et al., 2008; Paine et al., 2011). Insect herbivores associated with tropical Asian eucalypts are potential native colonizers of Australian eucalypt species introduced into Asia and conversely are considered a biosecurity risk to Australian eucalypt forests (Wylie and Floyd, 2002). Brazil is another good example: it has a high diversity of native (non-eucalypt) Myrtaceae and associated native insect herbivores [>200 spp. of mostly leaf chewing Lepidoptera and Coleoptera (Zanuncio et al., 1994; dos Anjos and Majer, 2003)] plus leaf cutting ants, Atta spp. (Ferreira-Filho et al., 2015). Such native insects have transferred readily onto introduced eucalypts and now dominate the insect fauna associated with Brazilian eucalypt plantations (Zanuncio et al., 1994; Paine et al., 2011). New Zealand, however, has similar numbers of native colonizers and Australian invaders on eucalypts (Withers, 2001) (Figure 3) despite the presence of some Myrtaceae in the native flora. New Zealand's insect herbivores may be less predisposed to colonize eucalypts because the New Zealand Myrtaceae are more distantly related to eucalypts than are the South American Myrtaceae (Ridley et al., 2000). Certainly geographic proximity, prevailing winds, and high trade volumes across the Tasman increase the likelihood of Australian insects reaching New Zealand (Fox, 1978; Sturman et al., 1997). North America and Europe have few native Myrtaceae and eucalypts in these regions are dominated by invasive Australian species (Paine et al., 2011).

A closer look at the variety of herbivores found on eucalypts outside Australia suggests herbivore guilds may play a role 


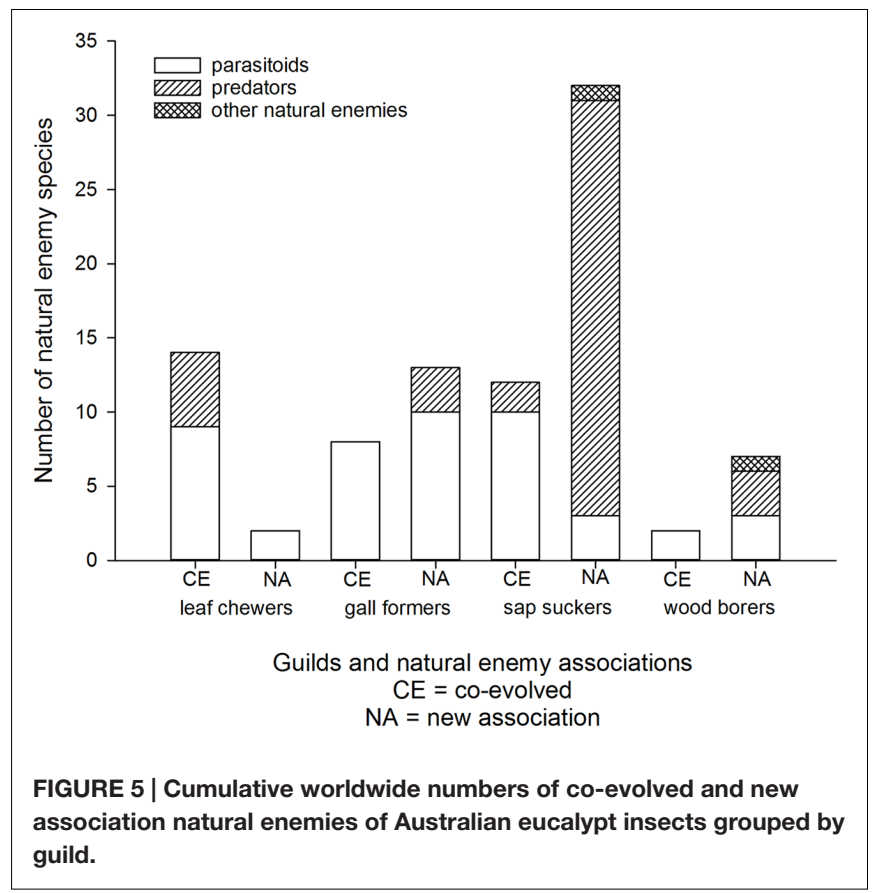

in the construction of new eucalypt communities, something first considered in New Zealand by Withers (2001). Australian invaders can be classified into guilds easily but the relative proportion of native colonizers will be an underestimate for most guilds because there is not sufficient information to assign every native colonizer to a guild. For those native colonizers that could be identified (Figure 4), native leaf chewers, wood borers, termites and sap suckers are more dominant on eucalypts than Australian members of those guilds whereas gall formers are almost exclusively invasive Australian species (a gall former is associated with E. deglupta in the Philippines where both herbivore and eucalypt are native, Speight and Wylie, 2001). Gall formers form highly specific relationships with their host plants (Raman et al., 2005) relative to the other guilds considered here and this host specificity may act to constrain colonization of eucalypts by native gall forming species. The lack of native gall forming colonizers on eucalypts may partly explain the extremely rapid invasion by the Australian gall former L. invasa because it took over a vacant niche in eucalypt communities worldwide. The sap sucking guild has a high proportion of native colonizers but also includes a suite of Australian invaders dominated by the eucalypt psyllids. The dominance of native colonizers in the leaf chewing and wood boring guilds, by pre-empting plant resources, may have made eucalypt plantations in Asia and South America less vulnerable to new Australian invaders from these guilds.

\section{NATURAL ENEMIES}

Most eucalypt herbivores are associated with an extensive parasitoid fauna within their native ranges (e.g., Austin and
Allen, 1989; Austin et al., 1994; Mendel et al., 2007). Escape from natural enemies is one factor expected to contribute to invasion success elsewhere (Liu and Stiling, 2006; Branco et al., 2014). Certainly invasive eucalypt insects are often targets for classical biological control (e.g., Faulds, 1991; Hodkinson, 1999; Tribe, 2000). Deliberate introductions of natural enemies (mostly host-specific parasitoids) are documented for eight of the eleven most invasive eucalypt herbivores and for at least another five species that are not as widespread (Garnas et al., 2012; Avila et al., 2013). Parasitoids are the most common co-evolved natural enemies associated with leaf chewers, gall formers, sap suckers, and wood borers, although there are some co-evolved predators associated with leaf chewers and sap suckers (Figure 5). It is important to recognize that not all Australian eucalypt herbivores cause significant damage once established in a new country and some remain at very low densities (Withers, 2001; Martinez et al., 2014). Planned biological control efforts have targeted those species that developed damaging populations.

Accidental introductions of co-evolved natural enemies into new countries have increased sharply since 2000 following a similar trend to that in planned introductions worldwide (Figure 6). Natural dispersal after planned biological control programs resulted in some accidental introductions to adjacent countries (Costanzi et al., 2003; Doganlar and Mendel, 2007). In other cases the natural enemy has arrived accidentally either together with, or very soon after, the pest (Branco et al., 2009; Burks et al., 2015a). Two accidental introductions of Australian hyperparasitoids associated with eucalypt insects and their parasitoids have been reported from New Zealand (Jones and Withers, 2003; Berry, 2007) but introductions at the fourth trophic level have not been reported elsewhere yet. No reports of natural enemies (co-evolved or new associations) were found from the invasive geographic range of 20 Australian eucalypt herbivores (eight leaf chewers, six gall formers, five sap suckers and one wood borer). Most of these species have invaded very few countries with just one gall former, Q. nova, that is widespread outside Australia.

New associations may form between invasive eucalypt herbivores and local natural enemies in the affected region(s). Eucalypt sap suckers seem to have been colonized by a higher proportion of local natural enemies compared with the other herbivore guilds (Figure 5). This includes the two invasive sap suckers, B. occidentalis and C. spatulata, which do not have any co-evolved natural enemies reported from their invasive geographic range. The only records of parasitism on the sap sucker B. occidentalis outside of Australia are by an unidentified local parasitoid in China (Yen et al., 2013) and by the newly described parasitoid species Psyllaephagus blastopsyllae in Cameroon (Tamesse et al., 2014). The majority of these new associations with sap suckers are due to generalist predators adapting to a new food source. For example, local generalist predator species (hoverflies, lacewings, predatory bugs, etc) have been recorded feeding on C. spatulata in Brazil and Portugal (Valente et al., 2004; Santana and Burckhardt, 2007), on Glycaspis brimblecombei in California (Erbilgin et al., 2004) and on 


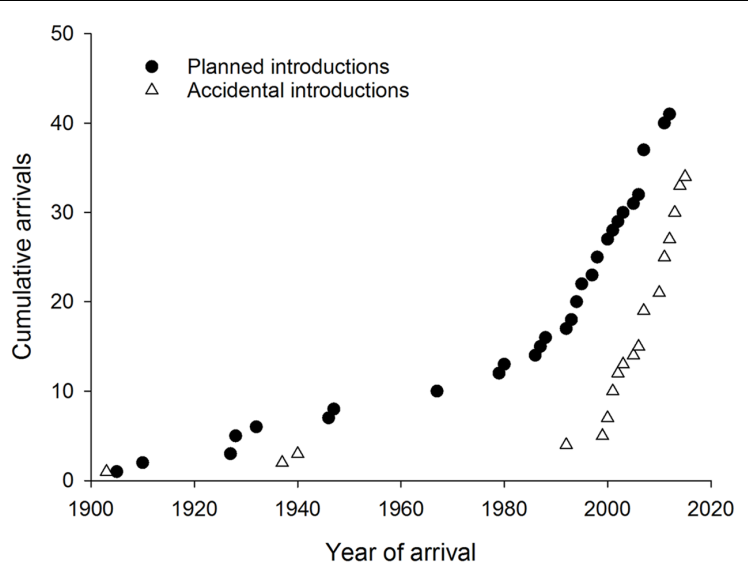

FIGURE 6 | Cumulative worldwide establishment of natural enemies associated with Australian eucalypt insects through planned (classical biological control) and accidental introductions.
T. peregrinus in Argentina (Santadino et al., 2013). There is one reported example where an Australian pest has arrived in a new country ( $T$. peregrinus in Portugal) in association with a new predator, the South American lacewing Hemerobius bolivari (Garcia et al., 2013). In Brazil the sap sucker T. peregrinus is also infected by an entomopathogenic fungus (Mascarin et al., 2012). The predator Anthocoris nemoralis attacks G. brimblecombei not only in the Palearctic region where the predator is native, but also in North America where this predator was introduced in the 1960s (Horton et al., 2004; Karaca et al., 2015).

New natural enemy associations recorded from the other herbivore guilds are linked with a single species in each case. The highly invasive gall former, $L$. invasa, is attacked by local parasitoid species in eight countries so far (Protasov et al., 2008; Doganlar et al., 2013; Udagedara and Karunaratne, 2014; Yang et al., 2014) and by several spider species in China (Zheng et al., 2014). Local parasitoids also attack the wood borer, P. semipunctata, in Morocco, California, and South Africa (Fraval and Haddan, 1988; Hanks et al., 1997; Prinsloo, 2004) while its eggs are subject to predation by ants in Portugal (Way et al., 1992). In Argentina P. semipunctata is also attacked by a nematode parasite (Achinelly and Camino, 2011). Two parasitoid species (one exotic, one presumed native) have formed new associations with the leaf chewer, U. lugens, in New Zealand (Mansfield et al., 2005). No new associations have been reported from the Gonipterus species complex, which are the most widespread leaf chewers.

When native insect herbivores colonize eucalypts, their natural enemies may follow them into this new habitat. This is best documented for the leaf chewing guild with very sparse records relating to natural enemies of native eucalypt colonizers in the wood borer (Noyes, 1990) and sap sucker (Speight and Wylie, 2001) guilds and no records at all for gall formers or termites. At least 12 native lepidopteran species (leaf chewers) feeding on introduced eucalypts have been associated with one or more natural enemies, mostly parasitoids. The majority of records are from Brazilian eucalypt plantations (e.g., de Campos and Cure, 1992; de Oliveira et al., 2000; Macedo-Reis et al., 2013) but there are also examples from East Africa, India, and Malaysia (Okelo, 1972; Joshi et al., 1988; Speight and Wylie, 2001). The predatory pentatomids (Podisus spp.) are the only co-evolved predators that attack native caterpillars colonizing eucalypts in Brazil, and are themselves attacked by several local species of egg parasitoid that have followed their hosts into the new eucalypt habitat (Zanuncio et al., 2000).

New associations have been recorded between two native Brazilian leaf chewers found on eucalypts, Thyrinteina arnobia and Melanolophia consimilaria, and the exotic parasitoid, Trichospilus diatraeae. This eulophid parasitoid was introduced to the Caribbean originally as a biological control agent for a sugarcane pest but it also attacks lepidopteran pests of other crops (Bennett et al., 1987). Its arrival in Brazil is presumed to be accidental (Pereira et al., 2008; Zache et al., 2010).

\section{CONCLUSION}

The earliest Australian invaders began to spread globally in the late 1800 s as eucalypt forestry developed outside of Australia. Australian eucalypt insects have continued to spread ever since. Some guilds (sap suckers, gall formers) have contributed more highly invasive species than others (wood borers, leaf chewers). Native colonizers, particularly leaf chewers, have also moved onto introduced eucalypts, increasing the diversity of new eucalypt communities. This trend is strongest in the tropical regions where biodiversity is high and the pool of potential native colonizers is largest. The observed patterns of invasion among different guilds suggest a new hypothesis: eucalypt communities that accumulate higher numbers of native colonizers from a particular guild (e.g., leaf chewers) will have greater biotic resistance to new invasions by Australian species from that same guild. It is challenging to test this hypothesis explicitly because it requires evidence not only of successful and failed invasions but also some measure of inter-specific competition within new eucalypt communities. Successful invasions are usually documented, as this review demonstrates, but data on border interceptions of particular insect groups are less readily available. The effects of competition between native colonizers and Australian invaders on invasion success warrants further investigation.

Biological control by co-evolved natural enemies can reduce the damage caused by Australian invaders, as the history of successful classical biological control programs shows. The impact of co-evolved natural enemies does not appear to prevent the spread of Australian invaders into new regions. Native natural enemies that form new associations with Australian invaders may also contribute to biological control, particularly for Australian sap suckers, which have a higher proportion of new associations than other guilds. Co-evolved natural enemies may contribute to control of native colonizers on eucalypts although the literature is still sparse on this point. Eucalypt communities outside Australia can now support unplanned invasions of the third, and occasionally even the fourth trophic levels. The increasing numbers of Australian invaders that have arrived simultaneously with their natural enemy demonstrate this point. The complexity 
of these new eucalypt communities is expected to increase in future.

\section{AUTHOR CONTRIBUTIONS}

The author confirms being the sole contributor of this work and approved it for publication.

\section{FUNDING}

Preparation of this review was supported by a Thompson Fellowship from the University of Sydney.

\section{REFERENCES}

Achinelly, M. F., and Camino, N. B. (2011). A new species of nematoda parasite of the cerambicid Eucalyptus longhorned borer from Argentina. Helminthologia 48, 203-206. doi: 10.2478/s11687-011-0030-6

Austin, A. D., and Allen, G. R. (1989). Parasitoids of Uraba lugens Walker (Lepidoptera: Noctuidae) in South Australia, with description of two new species of Braconidae. Trans. R. Soc. S. Aust. 113, 169-184.

Austin, A. D., Quicke, D. L. J., and Marsh, P. M. (1994). The hymenopterous parasitoids of eucalypt longicorn beetles, Phoracantha spp. (Coleoptera, Cerambycidae) in Australia. Bull. Entomol. Res. 84, 145-174. doi: 10.1017/ S000748530003964X

Avila, G. A., Berndt, L. A., and Holwell, G. I. (2013). First releases and monitoring of the biological control agent Cotesia urabae Austin and Allen (Hymenoptera: Braconidae). N. Z. Entomol. 36, 65-72. doi: 10.1080/00779962.2012.744908

Bain, J., and Jenkin, M. J. (1983). Kalotermes banksiae, Glyptotermes brevicornis, and other termites (Isoptera) in New Zealand. N. Z. Entomol. 7, 365-371. doi: 10.1080/00779962.1983.9722426

Bejakovich, D. (2002). Eradication not viable for new pests. Biosecurity 38:16.

Bennett, F. D., Glenn, H., Yaseen, M., and Baranowski, R. M. (1987). Records of Trichospilus diatraeae, an Asian parasite (Hymenoptera: Eulophidae) from the Caribbean and Florida. Florida Entomol. 70, 184-186. doi: 10.2307/3495110

Berry, J. A. (2007). Key to the New Zealand species of Psyllaephagus ashmead (Hymenoptera: Encyrtidae) with descriptions of three new species and a new record of the psyllid hyperparasitoid Coccidoctonus psyllae riek (Hymenoptera: Encyrtidae). Aust. J. Entomol. 46, 99-105. doi: 10.1111/j.1440-6055.2007. 00575.x

Berry, J. A., and Withers, T. M. (2002). New gall-inducing species of ormocerine pteromalid (Hymenoptera: Pteromalidae: Ormocerinae) described from New Zealand. Aust. J. Entomol. 41, 18-22. doi: 10.1046/j.1440-6055.2002.00257.x

Branco, M., Boavida, C., Durand, N., Franco, J. C., and Mendel, Z. (2009). Presence of the Eucalyptus gall wasp Ophelimus maskelli and its parasitoid Closterocerus chamaeleon in Portugal: first record, geographic distribution and host preference. Phytoparasitica 37, 51-54. doi: 10.1007/s12600-008-0010-7

Branco, M., Dhahri, S., Santos, M., and Ben Jamaa, M. L. (2014). Biological control reduces herbivore's host range. Biol. Control 69, 59-64. doi: 10.1016/j. biocontrol.2013.11.001

Brandle, M., Kuhn, I., Klotz, S., Belle, C., and Brandl, R. (2008). Species richness of herbivores on exotic host plants increases with time since introduction of the host. Divers. Distrib. 14, 905-912. doi: 10.1111/j.1472-4642.2008.00511.x

Burckhardt, D., Queiroz, D. L., and Malenovsky, I. (2014). First record of the Australian genus platyobria TAYLOR, 1987 from Europe and P. biemani sp nov as a potential pest of Eucalyptus (Myrtaceae) (Hemiptera: Psylloidea). Entomol. Z. 124, 109-112.

Burks, R. A., Mottern, J. L., Pownall, N., Waterworth, R., and Paine, T. D. (2015a). First record of Closterocerus chamaeleon, parasitoid of the Eucalyptus Gall Wasp Ophelimus maskelli (Hymenoptera, Chalcidoidea, Eulophidae), in the New World. Zookeys 504, 149-152.

Burks, R. A., Mottern, J. L., Waterworth, R., and Paine, T. D. (2015b). First report of the Eucalyptus gall wasp, Ophelimus maskelli (Hymenoptera: Eulophidae),

\section{ACKNOWLEDGMENT}

Comments from Toni Withers and Stephen Goldson improved an earlier version of this paper.

\section{SUPPLEMENTARY MATERIAL}

The Supplementary Material for this article can be found online at: http://journal.frontiersin.org/article/10.3389/fpls.2016.01812/ full\#supplementary-material

DATA SHEET 1 | Database of Australian invaders, native colonisers, and their associated natural enemies.

an invasive pest on Eucalyptus, from the Western Hemisphere. Zootaxa 3926, 448-450. doi: 10.11646/zootaxa.3926.3.10

CABI (2015a). Forestry Compendium. Wallingford: CAB International. CABI (2015b). Invasive Species Compendium. Wallingford: CAB International.

Common, I. F. B. (1980). Some factors responsible for imbalances in the Australian fauna of Lepidoptera. J. Lepidopterists' Soc. 34, 286-294.

Commonwealth of Australia (2015). Wood Packaging for Export. Available at: http: //www.agriculture.gov.au/export/wood-packaging [accessed October 29, 2015].

Constantino, R. (2002). The pest termites of South America: taxonomy, distribution and status. J. Appl. Entomol. 126, 355-365. doi: 10.1046/j.14390418.2002.00670.x

Costanzi, M., Frassetti, F., and Malausa, J. C. (2003). Biological control of the psyllid Ctenarytaina eucalypti maskell in Eucalyptus plantations of Ligurian Riviera. Inform. Fitopatol. 53, 52-56.

de Campos, W. G., and Cure, J. R. (1992). Parasitism of a natural population of Myonia pyraloides Walker, 1854 (Lepidoptera: Dioptidae), in Eucalyptus cloeziana reforestation. Anais Soc. Entomol. Brasil 21, 241-249.

De Menezes, C. W. G., Soares, M. A., De Assis Júnior, S. L., De Menezes, S. J. M. C., Dos Santos, J. B., and Zanuncio, J. C. (2013). Brontocoris tabidus (Heteroptera: Pentatomidae) preying on Podalia walkeri (Lepidoptera: Megalopygidae) on eucalypt plants in Brazil. Florida Entomol. 96, 261-263. doi: 10.1653/024.096. 0141

de Oliveira, H. N., Zanuncio, J. C., Pratissoli, D., and Cruz, I. (2000). Parasitism rate and viability of Trichogramma maxacalii (Hym.: Trichogrammatidae) parasitoid of the Eucalyptus defoliator Euselasia apison (Lep.: Riodinidae), on eggs of anagasta kuehniella (Lep.: Pyralidae). Forest Ecol. Manag. 130, 1-6. doi: 10.1016/S0378-1127(99)00172-3

Denno, R. F., McClure, M. S., and Ott, J. R. (1995). Interspecific interactions in phytophagous insects: competition reexamined and resurrected. Annu. Rev. Entomol. 40, 297-331. doi: 10.1146/annurev.en.40.010195.00 1501

Doganlar, M., and Mendel, Z. (2007). First record of the Eucalyptus gall wasp Ophelimus maskelli and its parasitoid, Closterocerus chamaeleon, in Turkey. Phytoparasitica 35, 333-335. doi: 10.1007/BF02980695

Doganlar, M., Zache, B., and Wilcken, C. F. (2013). A new species of Megastigmus (Hymenoptera: Torymidae: Megastigminae) from Brazil. Flor. Entomol. 96, 196-199. doi: 10.1653/024.096.0126

dos Anjos, N., and Majer, J. D. (2003). Leaf-eating beetles in Brazilian eucalypt plantations. Perth, WA: Curtin University of Technology.

Drinkwater, T. W. (1975). "The present pest status of eucalyptus borers Phoracantha spp," in Proceedings of the First Congress of the Entomological Society of Southern Africa, eds H. J. R. Durr, J. H. Giliomee, and S. Neser (Stellenbosch: The Society), 119-129.

Erbilgin, N., Dahlsten, D. L., and Chen, P.-Y. (2004). Intraguild interactions between generalist predators and an introduced parasitold of Glycaspis brimblecombei (Homoptera: Psylloidea). Biol. Control 31, 329-337. doi: 10. 1016/j.biocontrol.2004.06.010

Evans, J. (2009). “The history of tree planting and planted forests," in Planted Forests: Uses, Impacts and Sustainability, ed. J. Evans (Wallingford: CABI Publishing), 5-22. 
Faulds, W. (1991). Spread of Bracon phylacteophagus, a biocontrol agent of Phylacteophaga froggatti, and impact on host. N. Z. J. For. Sci. 21, 185-193.

Ferreira-Filho, P. J., Wilcken, C. F., Neves, D. A., Pogetto, M. H. F. A. D., Carmo, J. B., Guerreiro, J. C., et al. (2015). Does diatomaceous earth control leafcutter ants (Hymenoptera: Formicidae) in the Eucalyptus plantations? J. Econ. Entomol. 108, 1124-1128. doi: 10.1093/jee/tov066

Fox, K. J. (1978). The transoceanic migration of lepidoptera to New Zealand a history and a hypothesis on colonisation. N. Z. Entomol. 6, 368-380. doi: 10.1080/00779962.1978.9722295

Fraval, A., and Haddan, M. (1988). Platystasius transversus (Hymenoptera, Platygasteridae), an oophagous parasite of Phoracantha semipunctata (Coleoptera, Cerambycidae) in Morocco. Entomophaga 33, 381-382. doi: $10.1007 / \mathrm{BF} 02372629$

Garcia, A., Figueiredo, E., Valente, C., Monserrat, V. J., and Branco, M. (2013). First record of Thaumastocoris peregrinus in Portugal and of the neotropical predator Hemerobius bolivari in Europe. Bull. Insectol. 66, 251-256.

Garnas, J. R., Hurley, B. P., Slippers, B., and Wingfield, M. J. (2012). Biological control of forest plantation pests in an interconnected world requires greater international focus. Int. J. Pest Manag. 58, 211-223. doi: 10.1080/09670874. 2012.698764

Hanks, L. M., Campell, C., Paine, T. D., and Millar, J. G. (1997). Host range expansion of Helcostizus rufiscutum cushman (Hymenoptera: Ichneumonidae) to Phoracantha semipunctata Fabr (Coleoptera: Cerambycidae) in California. Pan-Pacific Entomol. 73, 190-191.

Hodkinson, I. D. (1999). Biocontrol of eucalyptus psyllid Ctenarytaina eucalypti by the Australian parasitoid Psyllaephagus pilosus: a review of current programmes and their success. Biocontrol News Inform. 20, 129N-134N.

Horton, D. R., Lewis, T. M., and Broers, D. A. (2004). Ecological and geographic range expansion of the introduced predator Anthocoris nemoralis (Heteroptera: Anthocoridae) in North America: potential for nontarget effects? Am. Entomol. 50, 18-30. doi: 10.1093/ae/50.1.18

Hui, C., Richardson, D. M., Visser, V., and Wilson, J. R. U. (2014). Macroecology meets invasion ecology: performance of Australian acacias and eucalypts around the world revealed by features of their native ranges. Biol. Invasions 16 , 565-576. doi: 10.1007/s10530-013-0599-4

Jones, D. C., and Withers, T. M. (2003). The seasonal abundance of the newly established parasitoid complex of the Eucalyptus tortoise beetle (Paropsis charybdis). N. Z. Plant Protect. 56, 51-55.

Joshi, K. C., Gurung, D., and Sarma, P. C. (1988). Some observations on the bionomics of Trabala vishnou Lef. (Lepidoptera: Lasiocampidae) - a pest of Eucalyptus spp. in Assam. J. Trop. For. 4, 285-289.

Kaplan, I., and Denno, R. F. (2007). Interspecific interactions in phytophagous insects revisited: a quantitative assessment of competition theory. Ecol. Lett. 10, 977-994. doi: 10.1111/j.1461-0248.2007.01093.x

Karaca, I., Kayahan, A., Simsek, B., and Celikpence, Y. (2015). First record of Glycaspis brimblecombei Moore (Hemiptera: Aphalaridae), in Turkey. Phytoparasitica 43, 171-175. doi: 10.1007/s12600-015-0457-2

Kim, I.-K., and La Salle, J. (2008). A new genus and species of Tetrastichinae (Hymenoptera: Eulophidae) inducing galls in seed capsules of Eucalyptus. Zootaxa 1745, 63-68.

Klein, H., Hoffmann, J. H., Neser, S., and Dittrich-Schroder, G. (2015). Evidence that Quadrastichodella nova (Hymenoptera: Eulophidae) is the only gall inducer among four hymenopteran species associated with seed capsules of Eucalyptus camaldulensis (Myrtaceae) in South Africa. Afr. Entomol. 23, 207-223. doi: 10.4001/003.023.0117

Liu, H., and Stiling, P. (2006). Testing the enemy release hypothesis: a review and meta-analysis. Biol. Invasions 8, 1535-1545. doi: 10.1007/s10530-005-5845-y

Macedo-Reis, L. E., Soares, L. G. S., De Faria, M. L., Do Espírito Santo, M. M., and Zanuncio, J. C. (2013). Survival of a lepidopteran defoliator of Eucalyptus is influenced by local hillside and forest remnants in Brazil. Flor. Entomol. 96, 941-947. doi: 10.1653/024.096.0331

Mansfield, S., Kriticos, D. J., Potter, K. J. B., and Watson, M. C. (2005). Parasitism of gum leaf skeletoniser (Uraba lugens) in New Zealand. N. Z. Plant Protect. 58, 191-196.

Mapondera, T. S., Burgess, T., Matsuki, M., and Oberprieler, R. G. (2012). Identification and molecular phylogenetics of the cryptic species of the Gonipterus scutellatus complex (Coleoptera: Curculionidae:
Gonipterini). Aust. J. Entomol. 51, 175-188. doi: 10.1111/j.1440-6055.2011. 00853.x

Martinez, G., Gomez, D., and Taylor, G. S. (2014). First record of the Australian psyllid Blastopsylla occidentalis Taylor (Hemiptera, Psylloidea) from Uruguay. Trans. R. Soc. S. Aust. 138, 231-236. doi: 10.1080/03721426.2014.11649010

Martoni, F., Burckhardt, D., and Armstrong, K. (2016). An annotated checklist of the psyllids of New Zealand (Hemiptera: Psylloidea). Zootaxa 4144, 556-574. doi: 10.11646/zootaxa.4144.4.6

Mascarin, G. M., da Silveira Duarte, V., Brandão, M. M., and Delalibera, I. (2012). Natural occurrence of Zoophthora radicans (Entomophthorales: Entomophthoraceae) on Thaumastocoris peregrinus (Heteroptera: Thaumastocoridae), an invasive pest recently found in Brazil. J. Invertebr. Pathol. 110, 401-404. doi: 10.1016/j.jip.2012.03.025

Mendel, Z., Protasov, A., Blumberg, D., Brand, D., Saphir, N., Madar, Z., et al. (2007). Release and recovery of parasitoids of the Eucalyptus gall wasp Ophelimus maskelli in Israel. Phytoparasitica 35, 330-332. doi: 10.1007/ BF02980694

Mendel, Z., Protasov, A., Fisher, N., and La Salle, J. (2004). Taxonomy and biology of Leptocybe invasa gen. \& sp n. (Hymenoptera: Eulophidae), an invasive gall inducer on Eucalyptus. Aust. J. Entomol. 43, 101-113. doi: 10.1111/j.1440-6055. 2003.00393.x

Mound, L. A., and Walker, A. K. (2012). The Australia-New Zealand connection re-visited, with two new species of Cartomothrips (Thysanoptera, Phlaeothripinae). Zootaxa 3487, 58-64.

Nahrung, H. F., and Swain, A. J. (2015). Strangers in a strange land: do life history traits differ for alien and native colonisers of novel environments? Biol. Invas. 17, 699-709. doi: 10.1007/s10530-014-0761-7

Nair, K. S. S. (2007). Tropical Forest Insect Pests: Ecology, Impact, and Management. Cambridge: Cambridge University Press.

Noack, A. E., and Coviella, C. E. (2006). Thaumastocoris australicus kirkaldy (Hemiptera: Thaumastocoridae): first record of this invasive pest of Eucalyptus in the Americas. Gen. Appl. Entomol. 35, 13-14.

Noyes, J. S. (1990). A new genus and species of encyrtid (Hymenoptera, Chalcidoidea) parasitoid of the eggs of the varicose borer, Agrilus sexsignatus (Fisher) (Coleoptera, Buprestidae), a pest of bagras (Eucalyptus deglupta Blume) in the Philippines. J. Nat. History 24, 21-25. doi: 10.1080/ 00222939000770031

Nugnes, F., Gebiola, M., Monti, M. M., Gualtieri, L., Giorgini, M., Wang, J., et al. (2015). Genetic diversity of the invasive gall wasp Leptocybe invasa (Hymenoptera: Eulophidae) and of its Rickettsia Endosymbiont, and associated sex-ratio differences. PLoS ONE 10:e0124660. doi: 10.1371/journal.pone. 0124660

Ohmart, C. P., and Edwards, P. B. (1991). Insect herbivory on Eucalyptus. Annu. Rev. Entomol. 36, 637-657. doi: 10.1146/annurev.en.36.010191.003225

Okelo, O. (1972). Life history studies of Gonometa podocarpi Aurivillius (Lepidoptera: Lasiocampidae) in East Africa. Ohio J. Sci. 72, 301-303.

Paine, T. D., Millar, J. C., and Daane, K. M. (2010). Accumulation of pest insects on Eucalyptus in California: random process or smoking gun. J. Econ. Entomol. 103, 1943-1949. doi: 10.1603/EC10214

Paine, T. D., and Millar, J. G. (2002). Insect pests of eucalypts in California: implications of managing invasive species. Bull. Entomol. Res. 92, 147-152. doi: 10.1079/BER2002151

Paine, T. D., Steinbauer, M. J., and Lawson, S. A. (2011). Native and exotic pests of Eucalyptus: a worldwide perspective. Annu. Rev. Entomol. 56, 181-201. doi: 10.1146/annurev-ento-120709-144817

Pearson, H. G., Bennett, S. J., Philip, B. A., and Jones, D. C. (2010). The Australian dampwood termite, Porotermes adamsoni, in New Zealand. N. Z. Plant Protect. $63,241-247$.

Pereira, F. F., Zanuncio, J. C., Tavares, M. T., Pastori, P. L., Jacques, G. C., and Vilela, E. F. (2008). New record of Trichospilus diatraeae as a parasitoid of the eucalypt defoliator Thyrinteina arnobia in Brazil. Phytoparasitica 36, 304-306. doi: $10.1007 / \mathrm{BF} 02980777$

Philip, B., Pearson, H., and Bennett, S. (2008). Australian termites in New Zealand. Biosecurity 82, 12-13.

Potter, K. J. B., and Stephens, A. E. A. (2005). Suitability of valued eucalypt species for the larval development of the gum leaf skeletoniser, Uraba lugens. N. Z. Plant Protect. 58, 184-190. 
Prinsloo, G. L. (2004). Oxysychus genualis (Walker) (Hymenoptera: Pteromalidae): first record of an indigenous parasitoid of the introduced eucalyptus borer, Phoracantha semipunctata (Coleoptera: Cerambycidae), in South Africa. Afr. Entomol. 12, 271-274.

Protasov, A., Doganlar, M., La Salle, J., and Mendel, Z. (2008). Occurrence of two local megastigmus species parasitic on the Eucalyptus gall wasp leptocybe invasa in israel and Turkey. Phytoparasitica 36, 449-459. doi: 10.1007/BF030 20291

Protasov, A., La Salle, J., Blumberg, D., Brand, D., Saphir, N., Assael, F., et al. (2007). Biology, revised taxonomy and impact on host plants of Ophelimus maskelli, an invasive gall inducer on Eucalyptus spp. in the Mediterranean area. Phytoparasitica 35, 50-76. doi: 10.1007/BF02981061

Pryor, L. D., Williams, E. R., and Gunn, B. V. (1995). A morphometric analysis of Eucalyptus urophylla and related taxa with descriptions of 2 new species. Aust. Syst. Bot. 8, 57-70. doi: 10.1071/SB9950057

Raman, A., Schaefer, C. W., and Withers, T. M. (2005). Biology, Ecology and Evolution of Gall-Inducing Arthropods. Enfield, CT: Science Publishers, Inc.

Ramanagouda, S. H., Kumari, N. K., Vastrad, A. S., Basavana Goud, K., and Kulkarni, H. (2010). Potential alien insects threatening eucalyptus plantations in India. Karnataka J. Agric. Sci. 23, 93-96.

Rassati, D., Faccoli, M., Toffolo, E. P., Battisti, A., and Marini, L. (2015). Improving the early detection of alien wood-boring beetles in ports and surrounding forests. J. Appl. Ecol. 52, 50-58. doi: 10.1111/1365-2664.12347

Reid, C. A. M., and De Little, D. W. (2013). A new species of paropsisterna motschulsky, 1860, a significant pest of plantation eucalypts in Tasmania and Ireland (Coleoptera: Chrysomelidae: Chrysomelinae). Zootaxa 3681, 395-404. doi: 10.11646/zootaxa.3681.4.4

Ridley, G. S., Bain, J., Bulman, L. S., Dick, M. A., and Kay, M. K. (2000). Threats to New Zealand's indigenous forests from exotic pathogens and pests. Sci. Conserv. 142:68.

Santadino, M. V., Riquelme Virgala, M. B., and Coviella, C. E. (2013). First record of native predators on the invasive species Thaumastocoris peregrinus (Hemiptera: Thaumastocoridae) in Eucalyptus in Argentina. Rev. Soc. Entomol. Argent. 72, 219-222.

Santana, D. L. Q., and Burckhardt, D. (2007). Introduced Eucalyptus psyllids in Brazil. J. For. Res. 12, 337-344. doi: 10.1007/s10310-007-0035-7

Sopow, S., George, S., and Ward, N. (2012). Bronze bug, Thaumastocoris peregrinus: a new Eucalyptus pest in New Zealand. Surveillance 39, 43-46.

Sopow, S., Gresham, B., and Bain, J. (2015). Exotic longicorn beetles (Coleoptera: Cerambycidae) established in New Zealand. N. Z. Entomol. 38, 107-125. doi: 10.1080/00779962.2014.993798

Speight, M. R., and Wylie, F. R. (2001). Insect Pests in Tropical Forestry. Wallingford: CABI Publishing.

Sturman, A. P., Tyson, P. D., and D’Abreton, P. C. (1997). A preliminary study of the transport of air from Africa and Australia to New Zealand. J. R. Soc. N. Z. 27, 485-498. doi: 10.1080/03014223.1997.9517550

Tamesse, J. L., Soufo, L., Tchanatame, E. C., Dzokou, V. J., Gumovsky, A., and De Coninck, E. (2014). Description of Psyllaephagus blastopsyllae sp.n. (Encyrtidae), new species, endoparasitoid of Blastopsylla occidentalis Taylor (Psyllidae, Spondyliaspidinae) in Cameroon. J. Biodivers. Environ. Sci. 5, 227-236.

Timberlake, P. H. (1957). A new entedontine chalcid-fly from seed capsules of Eucalyptus in California (Hymenoptera: Eulophidae). Pan-Pacific Entomol. 33, 109-110.

Tribe, G. D. (2000). Ecology, distribution and natural enemies of the Eucalyptusdefoliating tortoise beetle Trachymela tincticollis (Blackburn) (Chrysomelidae: Chrysomelini: Paropsina) in southwestern Australia, with references to its biological control in South Africa. Afr. Entomol. 8, 23-45.

Tribe, G. D., Dutoit, A. P., Vanrensburg, N. J., and Johannsmeier, M. F. (1989). The collection and release of Tetrastichus sp. (Eulophidae) as a biological control agent for Drosophila flavohirta malloch (Drosophilidae) in South Africa. J. Entomol. Soc. S. Afr. 52, 181-182.

Udagedara, U. K. S. K., and Karunaratne, W. A. I. P. (2014). Biology, damage and parasitoids of the Eucalyptus gall wasp, Leptocybe invasa (Hymenoptera: Eulophidae), infesting Eucalyptus camaldulensis (Myrtaceae) in Maragamuwa plantation, Sri Lanka. Int. J. Trop. Insect Sci. 34, 179-189.
Valente, C., Manta, A., and Vaz, A. (2004). First record of the Australian psyllid Ctenarytaina spatulata taylor (Homoptera: Psyllidae) in Europe. J. Appl. Entomol. 128, 369-370. doi: 10.1111/j.1439-0418.2004.00860.x

Wang, Q. (1995). A taxonomic revision of the Australian genus Phoracantha Newman (Coleoptera: Cerambycidae). Invert. Taxon. 9, 865-958. doi: 10.1071/ IT9950447

Wardell-Johnson, G. M., Williams, J. E., and Hill, K. D. (1997). "Evolutionary biogeography and contemporary distribution of eucalypts," in Eucalypt Ecology: Individuals to Ecosystems, eds J. E. Williams and J. Woinarski (Cambridge: Cambridge University Press), 92-128.

Way, M. J., Cammell, M. E., and Paiva, M. R. (1992). Studies on egg predation by ants (Hymenoptera: Formicidae) especially on the eucalyptus borer Phoracantha semipunctata (Coleoptera: Cerambycidae) in Portugal. Bull. Entomol. Res. 82, 425-432. doi: 10.1017/S0007485300041225

Wingfield, M. J., Slippers, B., Hurley, B. P., Coutinho, T. A., Wingfield, B. D., and Roux, J. (2008). Eucalypt pests and diseases: growing threats to plantation productivity. South. For. 70, 139-144. doi: 10.2989/SOUTH.FOR.2008.70.2.9. 537

Withers, T. M. (2001). Colonization of eucalypts in New Zealand by Australian insects. Aust. Ecol. 26, 467-476. doi: 10.1046/j.1442-9993.2001.01140.x

Wylie, F. R., and Floyd, R. B. (2002). The insect threat to eucalypt plantations in tropical areas of Australia and Asia. For. Res. Supp. Program. Asia Pacific (FORSPA) Pub. 30, 11-17.

Yang, M.-M., Lin, Y.-C., Wu, Y., Fisher, N., Saimanee, T., Sangtongpraow, B., et al. (2014). Two new Aprostocetus species (Hymenoptera: Eulophidae: Tetrastichinae), fortuitous parasitoids of invasive eulophid gall inducers (Tetrastichinae) on Eucalyptus and Erythrina. Zootaxa 3846, 261-272. doi: 10.11646/zootaxa.3846.2.6

Yen, A. L., Burckhardt, D., and Cen, Y.-J. (2013). The occurrence of the Australian psyllid Blastopsylla occidentalis Taylor (Hemiptera, Psylloidea) from China. Dongwu Fenlei Xuebao 38, 436-439.

Zache, B., Wilcken, C. F., da Costa, R. R., and Soliman, E. P. (2010). Trichospilus diatraeae cherian \& margabandhu, 1942 (Hymenoptera: Eulophidae), a new parasitoidof Melanolophia consimilaria (Lepidoptera: Geometridae). Phytoparasitica 38, 355-357. doi: 10.1007/s12600-010-0108-6

Zanuncio, J. C., do Nascimento, E. C., Garcia, J. F., and Zanuncio, T. V. (1994). Major lepidopterous defoliators of eucalypt in southeast Brazil. For. Ecol. Manag. 65, 53-63. doi: 10.1016/0378-1127(94)90257-7

Zanuncio, J. C., Oliveira, H. N., Torres, J. B., and Pratissoli, D. (2000). Egg parasitoids of Podisus sculptus distant (Heteroptera: Pentatomidae) in an Eucalyptus plantation in the Brazilian Amazonian Region. Rev. Biol. Trop. 48, 989-992.

Zheng, X. L., Li, J., Yang, Z. D., Xian, Z. H., Wei, J. G., Lei, C. L., et al. (2014). A review of invasive biology, prevalence and management of Leptocybe invasa fisher \& la salle (Hymenoptera: Eulophidae: Tetrastichinae). Afr. Entomol. 22, 68-79. doi: $10.4001 / 003.022 .0326$

Zhenghong, P. (2003). "Insect pests of eucalypts in China," in Eucalypts in Asia. Australian Centre for International Agricultural Research, ed. J. W. Turnbull (Zhanjiang: Guangdong, People's Republic of China), 183-184.

Zhu, F.-L., Ren, S.-X., Qiu, B.-L., Huang, Z., and Peng, Z.-Q. (2012). The abundance and population dynamics of Leptocybe invasa (Hymenoptera: Eulophidae) galls on Eucalyptus spp. in China. J. Integr. Agric. 11, 2116-2123. doi: 10.1016/S20953119(12)60470-5

Zondag, R. (1979). A checklist of insects attacking eucalypts in New Zealand. N. Z. J. For. Sci. $24,85-89$.

Conflict of Interest Statement: The author declares that the research was conducted in the absence of any commercial or financial relationships that could be construed as a potential conflict of interest.

Copyright (c) 2016 Mansfield. This is an open-access article distributed under the terms of the Creative Commons Attribution License (CC BY). The use, distribution or reproduction in other forums is permitted, provided the original author(s) or licensor are credited and that the original publication in this journal is cited, in accordance with accepted academic practice. No use, distribution or reproduction is permitted which does not comply with these terms. 